\title{
Recent advances in the genetics of language impairment
}

\author{
Dianne F Newbury*, Simon E Fisher and Anthony P Monaco
}

\begin{abstract}
Specific language impairment (SLI) is defined as an unexpected and persistent impairment in language ability despite adequate opportunity and intelligence and in the absence of any explanatory medical conditions. This condition is highly heritable and affects between $5 \%$ and $8 \%$ of pre-school children. Over the past few years, investigations have begun to uncover genetic factors that may contribute to susceptibility to language impairment. So far, variants in four specific genes have been associated with spoken language disorders - forkhead box P2 (FOXP2) and contactinassociated protein-like 2 (CNTNAP2) on chromosome 7 and calcium-transporting ATPase 2C2 (ATP2C2) and C-MAF inducing protein (CMIP) on chromosome 16. Here, we describe the different ways in which these genes were identified as candidates for language impairment. We discuss how characterization of these genes, and the pathways in which they are involved, may enhance our understanding of language disorders and improve our understanding of the biological foundations of language acquisition.
\end{abstract}

\section{Introduction}

Language is a quintessential human trait that, for the most part, proceeds along a recognized trajectory with minimal explicit instruction [1]. In some cases, however, language acquisition is not so straightforward and language ability is delayed or permanently impaired. Sometimes these impairments form part of a recognized medical condition (such as learning deficit, autism or deafness), but often no obvious cause can be identified. In such cases, the language deficit is usually classified as specific language impairment (SLI) [2]. As such, SLI is usually diagnosed through exclusionary criteria rather

*Correspondence: dianne@well.ox.ac.uk

Wellcome Trust Centre for Human Genetics, University of Oxford, Roosevelt Drive, Headington, Oxford OX3 7BN, UK than on the basis of any specific clinical test. SLI affects between $5 \%$ and $8 \%$ of English-speaking (primarily UK and US) pre-school children, and is a lifelong disability with an increased risk of behavioral disorders, social problems and literacy deficits [3-5]. The disorder shows significant overlap with associated developmental conditions, such as attention deficit hyperactivity disorder (ADHD), speech sound disorder (SSD), dyslexia and autism [6].

Over the past decade, researchers have begun to identify genetic factors that may have roles in the etiology of language disorders. It is hoped that the study of these genes will facilitate a better understanding of the cause of language impairments, leading to the development of improved diagnostic and treatment strategies for affected individuals. In turn, knowledge regarding the cause of such impairments may further our understanding of the biological pathways that underpin normal language acquisition [7].

Here, we focus on specific genes that have been identified to have a role in language impairment. Genetic linkage and association studies of SLI and related learning disorders are reviewed elsewhere [8-10].

\section{FOXP2}

Until recently, the only gene that had been directly implicated in the etiology of speech and language disorders was the FOXP2 gene on chromosome 7q (OMIM 605317). In 2001, a study by Lai and colleagues [11] implicated mutation of FOXP2 in a monogenic form of speech and language disorder found in a three-generation pedigree (the KE family) and in an unrelated individual with a chromosome translocation. In both cases, the disorder was characterized by verbal (or articulatory) dyspraxia, that is, difficulties controlling the movement and sequencing of orofacial muscles, causing deficits in the production of fluent speech. In-depth studies of the KE family showed that, in these individuals, speech production problems are accompanied by a complex array of linguistic deficits that include varying degrees of expressive and written language problems and, in some members, nonverbal cognitive impairments [12]. Subsequent screening studies have shown that although FOXP2 
mutations are unlikely to be involved in the etiology of typical forms of SLI [13,14], heterozygous disruptions of this gene (point mutations or chromosomal rearrangements) invariably lead to syndromes that include aspects of verbal dyspraxia [15-21].

The FOXP2 gene encodes a transcription factor that regulates the expression of other genes. Downstream target screening studies have highlighted a variety of genes that may be regulated by FOXP2 and indicate that the effect of FOXP2 can vary greatly between tissues and developmental time points [22-24]. FOXP2 may thus be involved in a variety of biological pathways and cascades that may ultimately influence language development. Pathway analyses of the identified targets indicate an enrichment of genes involved in the functioning, development and patterning of the central nervous system. In analyses of human neuronal cell models, Vernes et al. [23] estimated that FOXP2 may bind directly to approximately 300 to 400 gene promoters in the human genome. Although statistically significant overlaps were seen between the individual studies of FOXP2 targets, there were also notable differences in the sets of downstream genes that were identified. This finding demonstrates the complexity of these regulatory pathways and the inherent difficulties of precisely defining them in the laboratory.

\section{FOXP2 in the brain}

The expression of FOXP2 is not limited to the brain but is also seen in several other organs, primarily those derived from the foregut endoderm, such as the lungs and esophagus [25]. In the human brain, FOXP2 is expressed in a range of regions, including sensory and limbic nuclei, the cerebral cortex and several motor structures, particularly the striatum and cerebellum [26,27]. Within these anatomical areas, FOXP2 expression is often limited to selected subdivisions or neuron types (for example, deep layers of the cortex, medium spiny neurons in the striatum and Purkinje cells in the cerebellum).

Mice that are bred to carry disruptions of both copies of Foxp 2 survive only a few weeks. They are small for their age and have widespread developmental delays, severe motor abnormalities and impaired cerebellar growth [28-32]. Given that total absence of functional Foxp2 results in lethality, in-depth behavioral investigations have focused on heterozygous mouse models, which carry a single working copy of Foxp2. Note that this matches the heterozygous state of humans with FOXP2 mutations; no humans carrying homozygous mutations have ever been identified. In general, it is found that these animals have normal motor skills and no obvious gross abnormalities. However, in-depth behavioral and morphological profiling has uncovered subtle deficits. Interestingly, two groups have reported that heterozygous pups produce fewer innate ultrasonic vocalizations than wild-type animals $[28,30]$. Other groups have questioned the reliability of this finding, instead describing deficits in motor skill learning [31], abnormal synaptic plasticity in striatal and cerebellar neural circuits [31] and differences in auditory brainstem responses [32] in heterozygous pups. In song-birds, it has been reported that reducing the expression of FoxP2 in an area of the brain necessary for vocal learning can interfere with the song learning process [33]. For an indepth discussion of these animal studies, see [34].

Brain imaging studies of KE family members have also revealed structural and functional abnormalities in the cerebellum and striatum $[12,35,36]$. Affected individuals were found to have reduced gray matter densities in the caudate nucleus, the cerebellum, the inferior frontal gyrus and the lower primary motor cortex [12,35]. During the performance of language-related tasks, in contrast to the expected left-lateralized pattern of activation, affected members of the KE family showed bilateral, diffuse activation with little or no activity in the left inferior frontal cortex (which includes Broca's area, involved in speech production) and reduced activation in other speech-related cortical and sub-cortical brain regions. In addition, brain areas not usually activated during linguistic tasks, including the posterior parietal, occipital and postcentral regions, were found to be overactivated in affected individuals [36].

\section{Evolution of FOXP2}

Because of the proposed function of FOXP2 in speech and language development, this gene has been widely investigated from an evolutionary perspective. Versions of FOXP2 are found in many organisms and show striking similarities in terms of sequence and expression patterns across vertebrate species [26,27,33,37-39]. Aside from a difference in polyglutamine tract length, there are only three coding changes between the mouse and human versions of the FOXP2 gene, making it one of the most highly conserved genes found in comparisons of humanrodent genomes [38,39]. Interestingly, analyses of primates demonstrated that two of these three changes occurred in the human lineage after splitting from the chimpanzee and found additional signs that FOXP2 may have undergone accelerated evolution in humans $[38,39]$. Population modeling estimated that the gene was subject to positive selection approximately 200,000 years ago, a period that coincides with, or is subsequent to, the emergence of modern humans $[38,39]$. Note, however, that the errors attached to these estimates are large. Moreover, subsequent sequencing of paleontological samples has identified the human-specific coding changes of FOXP2 in Neanderthal tissues, which suggests a more ancient origin, given that Neanderthals split from 
humans at least 400,000 years ago [40]. Thus, the interpretation of these data is still under debate [41].

Two studies have investigated the functional differences between the human version of FOXP2 and that found in the chimpanzee. Enard et al. [42] reported that when human-specific coding changes were engineered in mice (partially 'humanizing' them at the locus), this resulted in an altered structure of innate pup vocalizations, decreased levels of exploration, decreased levels of dopamine in the brain and an increased dendrite length and synaptic plasticity in the striatum. These findings are intriguing, given that mice carrying disrupted versions of Foxp2 (described above) showed contrasting alterations in similar developmental areas. Konopka et al. [24] investigated potential differences in the functionality of the human and chimpanzee versions of FOXP2 [24]. They identified 116 genes that were differentially expressed between neuronal cell lines engineered to express either the human or the chimpanzee protein. They postulated that the identified set of genes may represent a biological network that could have a role in the evolution of human language, noting that the identified targets included genes involved in cerebellar motor function, craniofacial formation, cartilage and connective tissue formation [24].

In conclusion, although the exact contributions of FOXP2 to the development of speech and language remain unclear, the consensus from expression studies, neuro-imaging data and animal models is that this gene is of particular importance in the central nervous system, such that its dysfunction disturbs the development and function of the motor cortex, striatum and cerebellum. Investigations of the properties of FOXP2 and its downstream targets are beginning to identify networks of genes that could be crucial players in neural circuits that facilitate language acquisition.

\section{CNTNAP2}

The CNTNAP2 gene on chromosome 7q (OMIM 604569) was the first gene to be associated with genetically complex forms of SLI. This association was achieved through a candidate gene approach that arose from downstream target screening studies of FOXP2 [43]. Vernes et al. [43] discovered that FOXP2 directly binds a regulatory region of the CNTNAP2 gene. CASPR2, the protein encoded by CNTNAP2, is a member of the neurexin family, a family that is particularly interesting from a functional point of view as members are known to interact with neuroligins to adhere presynaptic neuronal membranes to postsynaptic ones. In the case of CASPR2, the protein mediates interactions between neurons and glia during nervous system development and is also involved in localization of potassium channels within differentiating axons $[44,45]$. Furthermore, both neurexins and neuroligins have been strongly implicated in autistic disorder, a neurodevelopmental condition that shows strong overlap with SLI [46-52].

The regulation of CNTNAP2 by FOXP2 was verified both in neuronal cell lines and in vivo (in human fetal cortical slices). In both of these experiments, the level of FOXP2 was found to be inversely correlated with that of CASPR2 [43]. An association analysis of 38 single nucleotide polymorphisms (SNPs) across CNTNAP2 was performed in 184 families ascertained by the SLI Consortium (SLIC). These families were identified by various different groups from across the UK but all contained a proband who, currently or in the past, had expressive and/or receptive language abilities more than 2 standard deviations (SD) below that expected for their age [53]. In accordance with SLI diagnostic guidelines, individuals with autistic features, signs of mental retardation or co-occurring medical conditions were excluded from this cohort. Three quantitative measures of language were considered in this group; composite scores of expressive and receptive language ability were derived from the Clinical Evaluation of Language Fundamentals battery (CELF-R) [54]. In addition, a measure of nonword repetition [55] was collected for all probands and siblings. This test involves the repetition of nonsensical words of increasing length and complexity and the results from it have been shown to be highly heritable and a consistent marker of the presence of language impairment. Non-word repetition is considered to be a measure of phonological short-term memory, leading to the proposal that short-term memory deficits may underlie some aspects of language impairment (reviewed in [56]). Nine single SNPs in CNTNAP2 showed association primarily with the non-word repetition phenotype but also with expressive and receptive language measures. The most strongly associated SNP was rs17236239 $\left(P=5.0 \times 10^{-5}\right)$, a variant that falls within an intronic sequence near the middle of the gene. This same region has also been implicated in a quantitative languagerelated trait (age at first word) in autism [57]. The exact mechanism by which the identified SNPs alter CNTNAP2 function has yet to be elucidated, but the integration of evidence from these various routes of investigation makes CNTNAP2 a compelling candidate for language disorders.

The CNTNAP2 gene has recently been implicated in multiple neurodevelopmental disorders, including Gilles de la Tourette syndrome [58], schizophrenia [59], epilepsy [59,60], autism [57,61-65], ADHD [66] and mental retardation [45] (Table 1 ). This diverse range of studies provides evidence for the disruption of CNTNAP2 by copy number variants (CNVs), gross chromosomal rearrangements and mutations as well as association with common variants. It remains unclear how one gene can contribute to such an array of neurological conditions, 
Table 1. Investigations implicating CNTNAP2 in neurological disorders

\begin{tabular}{|c|c|c|}
\hline Study & Trait & Gene disruption \\
\hline Vernes et al. 2008 [43] & SLI & None - association with common variants; candidate gene association study \\
\hline Zweier et al. 2009 [45] & $\begin{array}{l}\text { Mental retardation with seizures } \\
\text { (resembling Pitt-Hopkins syndrome) }\end{array}$ & Homozygous deletion in a single sib pair; point mutation in a single proband \\
\hline Alarcón et al. 2008 [57] & $\begin{array}{l}\text { Autism; quantitative measure of } \\
\text { 'age at first word' }\end{array}$ & $\begin{array}{l}\text { None - association with common variants; positional mapping of chromosome } 7 \\
\text { linkage region }\end{array}$ \\
\hline Verkerk et al. 2003 [58] & $\begin{array}{l}\text { Gilles de la Tourette syndrome with } \\
\text { obsessive compulsive disorder and } \\
\text { mental retardation }\end{array}$ & Complex chromosome rearrangement in a single family \\
\hline Friedman et al. 2008 [59] & $\begin{array}{l}\text { Epilepsy and schizophrenia } \\
\text { (one patient had autistic features and } \\
\text { mental retardation) }\end{array}$ & Deletion in three unrelated individuals \\
\hline Strauss et al. 2006 [60] & $\begin{array}{l}\text { Cortical dysplasia, focal epilepsy, } \\
\text { relative macrocephaly and } \\
\text { diminished deep-tendon reflexes }\end{array}$ & Point mutation; homozygosity mapping in isolated population \\
\hline Arking et al. 2008 [61] & Autism & None - association with common variants; genome-wide association \\
\hline Bakkaloglu et al. 2008 [62] & Autism & Inversion - single patient; coding changes - mutation screen in patient cohort \\
\hline Rossi et al. 2008 [63] & Autism and primary amenorrhea & Deletion - single patient \\
\hline Poot et al. 2009 [65] & Autism & Complex chromosome rearrangement in a single individual \\
\hline Elia et al. 2009 [66] & $\mathrm{ADHD}$ & Copy number variant - hemizygous deletion in a single proband \\
\hline Terracciano et al. 2008 [80] & $\begin{array}{l}\text { Openness to experience - the } \\
\text { tendency to be imaginative, creative, } \\
\text { unconventional, emotionally and } \\
\text { artistically sensitive; agreeableness }\end{array}$ & $\begin{array}{l}\text { None - association with common variants; genome-wide association of personality } \\
\text { dimensions }\end{array}$ \\
\hline
\end{tabular}

although it should be noted that the implicated disorders are not completely disparate and can be expected to involve some shared neuropathology. Nonetheless, it is obvious that CNTNAP2 must have vital roles in neuronal development and that perturbations of the function of this gene significantly increase the chances of some form of neurological dysfunction. It is likely that the differences in outcome are decided by a complex function that includes the nature of the mutation and both the genetic and environmental background of the affected individual. For example, it is feasible to consider that gene deletions may have different effects from point mutations, and that the consequence of a point mutation will vary according to its location in the protein or its effect on gene expression. Equally, one can see how different combinations of point mutations or common variants across gene networks may have divergent outcomes that depend on the exact genes involved.

It is likely that a gene such as CNTNAP2 functions in overlapping and intersecting neurodevelopmental pathways and thus even a seemingly subtle disruption of its function may affect a variety of processes. The eventual outcome at the organ or organism level may in turn be modulated by the ability of downstream genes and proteins to compensate for these variations. We can therefore view CNTNAP2 as a neuronal buffer; subtle disruptions of this gene alone may be insufficient to cause disorder but may place a critical load on neurological systems, which manifest in different ways depending on the nature of additional load factors. Once a critical threshold of load is exceeded, it is likely that neurological imbalance will ensue.

\section{ATP2C2 and CMIP}

The calcium-transporting ATPase $2 \mathrm{C} 2$ (ATP2C2) and c-MAF inducing protein (CMIP) genes, both on chromosome 16q, were identified as SLI candidates by a positional cloning approach, which involved a genomewide linkage study followed by a targeted high-density association investigation [53,67-70]. These phased investigations were performed using the SLIC sample, as described above [53]. Genome-wide linkage analyses in these families revealed a strong and consistent linkage signal on chromosome 16q with a measure of non-word repetition [53,67-69]. Association analyses of chromosome $16 \mathrm{q}$ indicated significant association with two clusters of SNPs, one between exons 2 and 5 of the CMIP gene (most significant $P=5.5 \times 10^{-7}$ ) and another 3 megabases distal between exons 7 and 12 of ATP2C2 (most significant $P=2.0 \times 10^{-5}$ ) [69]. Individuals carrying risk alleles at both these loci had an average non-word repetition score more than 1 SD below those carrying homozygous non-risk alleles. Association between $A T P 2 C 2$ and performance on the non-word repetition 
task was subsequently replicated in a language-impaired sample selected from a population cohort (most significant $P=0.006$ ) [69]. In this replication sample, some association was also observed with CMIP but in an opposite direction to that seen in the discovery cohort (most significant $P=0.02$ ) [69]. Although this does not preclude the presence of a genuine association, as it may be caused by differences in linkage disequilibrium patterns, it does highlight the need for careful interpretation of this result as well as for further replication in additional cohorts.

Both ATP2C2 and CMIP show expression in the brain and, although little is known about their role in this tissue, hypothetical links can be made between their putative functions and language and memory-related processes. The CMIP protein forms part of the cellular scaffold linking the plasma membrane to the cytoskeleton [71], and cytoskeletal remodeling represents a critical step in neuronal migration and synaptic formation processes. In addition, CMIP has been shown to interact with filamin $\mathrm{A}$ and nuclear factor $\kappa \mathrm{B}$, both of which have important neurological functions [72,73]. ATP2C2 is responsible for the removal of calcium and manganese from the cytosol into the Golgi body [74]. Calcium is an important ion in the regulation of many neuronal processes, including working memory, synaptic plasticity and neuronal motility [75], and manganese dysregulation has been linked to neurological disorders [76]. Interestingly, in a recent meta-analysis of genetic data for ADHD, which shows significant co-morbidity with SLI, chromosome $16 \mathrm{q}$ was highlighted as the most consistently linked region for this disorder [77]. Concurrent genome-wide association studies described significant association with a variant in $A T P 2 C 2$ [78], reinforcing the fact that, as discussed above, the correlation between genetic susceptibility and surface phenotype is far from straightforward.

As with CNTNAP2, the specific causal variants and the underlying mechanisms by which ATP2C2 and CMIP might contribute to language impairment have yet to be elucidated. The characterization of these factors will not only provide definitive evidence for the involvement of these genes but may also lead to the identification of further neurological pathways that contribute to language acquisition. Given the proposed reliance of non-word repetition performance on short-term memory ability, one can postulate that the investigation of $A T P 2 C 2$ and CMIP may provide a biological link between memoryrelated pathways and language acquisition. The fact that neither $A T P 2 C 2$ nor CMIP have been identified as downstream targets of FOXP2 suggests that the eventual combination of information from converging routes of investigation will enable the characterization of overlapping and interacting neurological systems that serve the acquisition of language.

\section{Conclusions}

The past few years have seen exciting progress in the genetics of language impairment. The increased knowledge of the FOXP2-dependent molecular networks has enabled the identification of brain regions and pathways that this gene may influence. Although FOXP2 mutations seem to contribute to only a relatively small number of language disorder cases, it seems likely that variations in the genes it controls, such as CNTNAP2, may be implicated in common forms of language impairment. Thus, as our understanding of downstream targets grows, so will our list of potential candidate genes for SLI. The association of CNTNAP2 variations with an array of developmental disorders indicates that alternative deficits may arise from the dysfunction of a neurological network, demonstrating the complexity of brain development processes.

Although the expression of FOXP2 seems to be particularly important for neurological mechanisms relevant to motor skills, we predict that $A T P 2 C 2$ and CMIP are likely to be involved in memory-related circuits. Thus, although language is unique to humans, we should not necessarily expect the pathways underlying it to be exclusive to humans. Processes such as memory and motor skills have key roles in language development, but they are certainly not specific to, and may not be completely essential for, language acquisition. Rather, we expect that a variety of pre-existing and diverse neurological pathways have been adapted to promote the development of human language [79]. Characterization of these pathways and the way they overlap and interact will be an enormous task but one that is becoming increasingly feasible thanks to advances in genetic techniques. Given the expected complexity of such pathways, it seems unlikely that the identification of genetic susceptibility factors will ever lead to the discovery of a 'cure' for SLI. Nonetheless, this is a worthwhile endeavor, as a better understanding of the causes of SLI will allow the development of better diagnostic systems and therapies for affected individuals. Furthermore, it is clear that the achievement of the ultimate goal - the elucidation of a genetic network underpinning language processes - will have an impact on our understanding not only of language impairment and acquisition, but also of human development, brain function and the neuropathology of associated developmental disorders.

\section{Abbreviations}

$\mathrm{ADHD}$, attention deficit hyperactivity disorder; ATP2C2, calcium-transporting ATPase 2C2; CMIP, c-MAF inducing protein; CNTNAP2, contactin-associated protein-like 2; FOXP2, forkhead box P2; SD, standard deviation; SLI, specific language impairment; SLIC, SLI Consortium; SNP, single nucleotide polymorphism.

Acknowledgements

We thank the patients and families who contributed DNA to these research projects. SEF is a Royal Society Research Fellow and is funded by the Royal 
Society, the Wellcome Trust and the Simons Foundation Autism Research Initiative. APM is funded by the Wellcome Trust.

\section{Authors' contributions}

DFN drafted the manuscript; APM and SEF assisted with its preparation and provided vital edits. All authors read the final manuscript and agreed its content before publication.

\section{Authors' information}

DFN is a post-doctoral researcher in APM's lab. She leads the SLI research project and was involved in the positional cloning of ATP2C2 and CMIP. SEF is a Royal Society Research Fellow and Reader in Molecular Neuroscience a the WTCHG, where he pioneers investigations into molecular mechanisms underlying speech and language. After working with APM on the identification of FOXP2, he became head of his own laboratory, which uses state-of-the-art methods to uncover how language-related genes influence the brain at multiple levels. APM is the head of the developmental neurogenetics group at the Wellcome Trust Centre for Human Genetics (WTCHG) in Oxford. His group works in two main areas: the genetics of neurodevelopmental disorders, including complex genetic diseases such as autism, specific language impairment and developmental dyslexia; and the positional cloning and functional characterization of monogenic neurologica diseases, including chorea acanthocytosis, speech and language disorder and Menkes disease. All three authors are members of the SLI Consortium.

\section{Competing interests}

The authors declare that they have no competing interests.

Published: 26 January 2010

\section{References}

1. Pinker S: The Language Instinct: The New Science of Language and Mind London: Allen Lane; 1994.

2. Bishop DV: Is specific language impairment a valid diagnostic category? Genetic and psycholinguistic evidence. Philos Trans R Soc Lond B Bio/ Sci 1994, 346:105-111.

3. Conti-Ramsden G, Durkin K: Language and independence in adolescents with and without a history of specific language impairment (SLI). J Speech Lang Hear Res 2008, 51:70-83.

4. Durkin K, Conti-Ramsden G: Language, social behavior, and the quality of friendships in adolescents with and without a history of specific language impairment. Child Dev 2007 , 78:1441-1457.

5. Whitehouse AJ, Watt HJ, Line EA, Bishop DV: Adult psychosocial outcomes of children with specific language impairment, pragmatic language impairment and autism. Int J Lang Commun Disord 2009, 44:511-528.

6. Pennington BF, Bishop DV: Relations among speech, language and reading disorders. Annu Rev Psych 2009, 60:283-306.

7. Plomin R, Haworth CM, Davis OS: Common disorders are quantitative traits. Nat Rev Genet 2009, 10:872-878.

8. Lewis BA, Shriberg LD, Freebairn LA, Hansen AJ, Stein CM, Taylor HG, lyengar SK: The genetic bases of speech sound disorders: evidence from spoken and written language. J Speech Lang Hear Res 2006, 49:1294-1312.

9. Paracchini S, Scerri T, Monaco AP: The genetic lexicon of dyslexia. Annu Rev Genomics Hum Genet 2007, 8:57-79.

10. Bishop DV: Genes, cognition, and communication: insights from neurodevelopmental disorders. Ann N Y Acad Sci 2009, 1156:1-18.

11. Lai CS, Fisher SE, Hurst JA, Vargha-Khadem F, Monaco AP: A forkhead-domain gene is mutated in a severe speech and language disorder. Nature 2001, 413:519-523.

12. Watkins KE, Dronkers NF, Vargha-Khadem F: Behavioural analysis of an inherited speech and language disorder: comparison with acquired aphasia. Brain 2002, 125:452-464

13. Newbury DF, Bonora E, Lamb JA, Fisher SE, Lai CS, Baird G, Jannoun L, Slonims V, Stott CM, Merricks MJ, Bolton PF, Bailey AJ, Monaco AP; International Molecular Genetic Study of Autism Consortium: FOXP2 is not a major susceptibility gene for autism or specific language impairment. Am J Hum Genet 2002, 70:1318-1327.

14. O'Brien EK, Zhang X, Nishimura C, Tomblin JB, Murray JC: Association of specific language impairment (SLI) to the region of 7q31. Am J Hum Genet 2003, 72:1536-1543.

15. Lai CS, Fisher SE, Hurst JA, Levy ER, Hodgson S, Fox M, Jeremiah S, Povey S,
Jamison DC, Green ED, Vargha-Khadem F, Monaco AP: The SPCH1 region on human 7q31: genomic characterization of the critical interval and localization of translocations associated with speech and language disorder. Am J Hum Genet 2000, 67:357-368.

16. MacDermot KD, Bonora E, Sykes N, Coupe AM, Lai CS, Vernes SC, Vargha-Khadem F, McKenzie F, Smith RL, Monaco AP, Fisher SE: Identification of FOXP2 truncation as a novel cause of developmental speech and language deficits. Am J Hum Genet 2005, 76:1074-1080.

17. Feuk L, Kalervo A, Lipsanen-Nyman M, Skaug J, Nakabayashi K, Finucane B, Hartung D, Innes M, Kerem B, Nowaczyk MJ, Rivlin J, Roberts W, Senman L, Summers A, Szatmari P, Wong V, Vincent JB, Zeesman S, Osborne LR, Cardy JO, Kere J, Scherer SW, Hannula-Jouppi K: Absence of a paternally inherited FOXP2 gene in developmental verbal dyspraxia. Am J Hum Genet 2006, 79:965-972.

18. Shriberg LD, Ballard KJ, Tomblin JB, Duffy JR, Odell KH, Williams CA: Speech, prosody, and voice characteristics of a mother and daughter with a 7;13 translocation affecting FOXP2. J Speech Lang Hear Res 2006, 49:500-525

19. Zeesman S, Nowaczyk MJ, Teshima I, Roberts W, Cardy JO, Brian J, Senman L, Feuk L, Osborne LR, Scherer SW: Speech and language impairment and oromotor dyspraxia due to deletion of 7q31 that involves FOXP2. Am J Med Genet A 2006, 140:509-514.

20. Lennon PA, Cooper ML, Peiffer DA, Gunderson KL, Patel A, Peters S, Cheung SW, Bacino CA: Deletion of 7q31.1 supports involvement of FOXP2 in language impairment: clinical report and review. Am J Med Genet A 2007, 143A:791-798.

21. Tomblin JB, O'Brien M, Shriberg LD, Williams C, Murray J, Patil S, Bjork J, Anderson S, Ballard K: Language features in a mother and daughter of a chromosome 7;13 translocation involving FOXP2. J Speech Lang Hear Res 2009, 52:1157-1174.

22. Spiteri E, Konopka G, Coppola G, Bomar J, Oldham M, Ou J, Vernes SC, Fisher SE, Ren B, Geschwind DH: Identification of the transcriptional targets of FOXP2, a gene linked to speech and language, in developing human brain. Am J Hum Genet 2007, 81:1144-1157.

23. Vernes SC, Spiteri E, Nicod J, Groszer M, Taylor JM, Davies KE, Geschwind DH, Fisher SE: High-throughput analysis of promoter occupancy reveals direct neural targets of FOXP2, a gene mutated in speech and language disorders. Am J Hum Genet 2007, 81:1232-1250.

24. Konopka G, Bomar JM, Winden K, Coppola G, Jonsson ZO, Gao F, Peng S, Preuss TM, Wohlschlegel JA, Geschwind DH: Human-specific transcriptional regulation of CNS development genes by FOXP2. Nature 2009, 462:213-217

25. Shu W, Lu MM, Zhang Y, Tucker PW, Zhou D, Morrisey EE: Foxp2 and Foxp1 cooperatively regulate lung and esophagus development. Development 2007, 134:1991-2000.

26. Lai CSL, Gerrelli D, Monaco AP, Fisher SE, Copp AJ: FOXP2 expression during brain development coincides with adult sites of pathology in a severe speech and language disorder. Brain 2003, 126:2455-2462.

27. Takahashi K, Liu FC, Hirokawa K, Takahashi H: Expression of Foxp2, a gene involved in speech and language, in the developing and adult striatum. J Neurosci Res 2003, 73:61-72.

28. Shu W, Cho JY, Jiang Y, Zhang M, Weisz D, Elder GA, Schmeidler J, De Gasper R, Sosa MA, Rabidou D, Santucci AC, Perl D, Morrisey E, Buxbaum JD: Altered ultrasonic vocalization in mice with a disruption in the Foxp2 gene. Proc Natl Acad Sci USA 2005, 102:9643-9648.

29. French CA, Groszer M, Preece C, Coupe AM, Rajewsky K, Fisher SE: Generation of mice with a conditional Foxp2 null allele. Genesis 2007, 45:440-446.

30. Fujita E, Tanabe Y, Shiota A, Ueda M, Suwa K, Momoi MY, Momoi T: Ultrasonic vocalization impairment of Foxp2 $(\mathrm{R} 552 \mathrm{H})$ knockin mice related to speech-language disorder and abnormality of Purkinje cells. Proc Natl Acad SciUSA 2008, 105:3117-3122.

31. Groszer M, Keays DA, Deacon RM, de Bono JP, Prasad-Mulcare S, Gaub S, Baum MG, French CA, Nicod J, Coventry JA, Enard W, Fray M, Brown SD, Nolan PM, Pääbo S, Channon KM, Costa RM, Eilers J, Ehret G, Rawlins JN, Fisher SE: Impaired synaptic plasticity and motor learning in mice with a point mutation implicated in human speech deficits. Curr Biol 2008, 18:354-362.

32. Kurt S, Groszer M, Fisher SE, Ehret G: Modified sound-evoked brainstem potentials in Foxp2 mutant mice. Brain Res 2009, 1289:30-36.

33. Haesler S, Wada K, Nshdejan A, Morrisey EE, Lints T, Jarvis ED, Scharff C: FoxP2 expression in avian vocal learners and non-learners. J Neurosci 2004 24:3164-3175

34. Fisher SE, Scharff C: FOXP2 as a molecular window into speech and 
language. Trends Genet 2009, 25:166-177.

35. Belton E, Salmond CH, Watkins KE, Vargha-Khadem F, Gadian DG: Bilateral brain abnormalities associated with dominantly inherited verbal and orofacial dyspraxia. Hum Brain Mapp 2003, 18:194-200.

36. Liégeois F, Baldeweg T, Connelly A, Gadian DG, Mishkin M, Vargha-Khadem F: Language fMRI abnormalities associated with FOXP2 gene mutation. Nat Neurosci 2003, 6:1230-1237.

37. Campbell P, Reep RL, Stoll ML, Ophir AG, Phelps SM: Conservation and diversity of Foxp2 expression in muroid rodents: functional implications. $J$ Comp Neurol 2009, 512:84-100

38. Enard W, Przeworski M, Fisher SE, Lai CS, Wiebe V, Kitano T, Monaco AP, Pääbo S: Molecular evolution of FOXP2, a gene involved in speech and language. Nature 2002, 418:869-872.

39. Zhang J, Webb DM, Podlaha O: Accelerated protein evolution and origins of human-specific features: FOXP2 as an example. Genetics 2002, 162:1825-1835

40. Krause J, Lalueza-Fox C, Orlando L, Enard W, Green RE, Burbano HA, Hublin JJ, Hänni C, Fortea J, de la Rasilla M, Bertranpetit, Rosas A, Pääbo: The derived FOXP2 variant of modern humans was shared by Neandertals. Curr Biol 2007, 17:1908-1912

41. Coop G, Bullaughey K, Luca F, Przeworski M: The timing of selection at the human FOXP2 gene. Mol Biol Evol 2008, 25:1257-1259.

42. Enard W, Gehre S, Hammerschmidt K, Hölter SM, Blass T, Somel M, Brückner MK, Schreiweis C, Winter C, Sohr R, Becker L, Wiebe V, Nickel B, Giger T, Müller U, Groszer M, Adler T, Aguilar A, Bolle I, Calzada-Wack J, Dalke C, Ehrhardt N, Favor J, Fuchs H, Gailus-Durner V, Hans W, Hölzlwimmer G, Javaheri A, Kalaydjiev S, Kallnik M, et al:: A humanized version of Foxp2 affects cortico-basal ganglia circuits in mice. Cell 2009, 137:961-971.

43. Vernes SJ, Newbury DF, Abrahams BS, Winchester L, Nicod J, Groszer M, Alarcón M, Oliver PL, Davies KE, Geschwind DH, Monaco AP, Fisher SE: A functional genetic link between distinct developmental language disorders. N Engl J Med 2008, 359:2337-2345.

44. Poliak S, Gollan L, Martinez R, Custer A, Einheber S, Salzer JL, Trimmer JS, Shrager P, Peles E: Caspr2, a new member of the neurexin superfamily, is localised at the juxtaparanodes of myelinated axons and associates with K+ channels. Neuron 1999, 24:1037-1047.

45. Zweier C, de Jong EK, Zweier M, Orrico A, Ousager LB, Collins AL, Bijlsma EK, Oortveld MAW, Ekici AB, Reis A, Schenck A, Rauch A: CNTNAP2 and NRXN1 are mutated in autosomal-recessive Pitt-Hopkins-like mental retardation and determine the level of a common synaptic protein in Drosophila. Am J Hum Genet 2009, 85:655-666.

46. Jamain S, Ouach H, Betancur C, Råstam M, Colineaux C, Gillberg IC Soderstrom H, Giros B, Leboyer M, Gillberg C, Bourgeron T; Paris Autism Research International Sibpair Study: Mutations of the X-linked genes encoding neuroligins NLGN3 and NLGN4 are associated with autism. Nat Genet 2003, 34:27-29.

47. Laumonnier F, Bonnet-Brilhault F, Gomot M, Blanc R, David A, Moizard MP, Raynaud M, Ronce N, Lemonnier E, Calvas P, Laudier B, Chelly J, Fryns JP, Ropers HH, Hamel BC, Andres C, Barthélémy C, Moraine C, Briault S: X-linked mental retardation and autism are associated with a mutation in the NLGN4 gene, a member of the neuroligin family. Am J Hum Genet 2004, 74:552-557.

48. Ylisaukko-oja T, Rehnström $\mathrm{K}$, Auranen M, Vanhala R, Alen R, Kempas E, Ellonen P, Turunen JA, Makkonen I, Riikonen R, Nieminen-von Wendt T, von Wendt L, Peltonen $L$, Järvelä I: Analysis of four neuroligin genes as candidates for autism. Eur J Hum Genet 2005, 13:1285-1292.

49. Yamakawa H, Oyama S, Mitsuhashi H, Sasagawa N, Uchino S, Kohsaka S, Ishiura S: Neuroligins 3 and $4 \mathrm{X}$ interact with syntrophin-gamma2, and the interactions are affected by autism-related mutations. Biochem Biophys Res Commun 2007, 355:41-46.

50. Jamain S, Radyushkin K, Hammerschmidt K, Granon S, Boretius S, Varoqueaux F, Ramanantsoa N, Gallego J, Ronnenberg A, Winter D, Frahm J, Fischer J, Bourgeron T, Ehrenreich $H$, Brose N: Reduced social interaction and ultrasonic communication in a mouse model of monogenic heritable autism. Proc Natl Acad Sci USA 2008, 105:1710-1715.

51. Lawson-Yuen A, Saldivar JS, Sommer S, Picker J: Familial deletion within NLGN4 associated with autism and Tourette syndrome. Eur J Hum Genet 2008, 16:614-618.

52. Yan J, Feng J, Schroer R, Li W, Skinner C, Schwartz CE, Cook EH Jr, Sommer SS: Analysis of the neuroligin $4 \mathrm{Y}$ gene in patients with autism. Psychiatr Genet 2008, 18:204-207.
53. The SLI Consortium: A genomewide scan identifies two novel loci involved in specific language impairment. Am J Hum Genet 2002, 70:384-398.

54. Semel EM, Wiig EH, Secord W: Clinical Evaluation of Language Fundamentals -Revised. San Antonio: Psychological Corporation; 1987.

55. Gathercole SE, Willis CS, Baddeley AD, Emslie H: The children's test of nonword repetition: a test of phonological working memory. Memory 1994, 2:103-107.

56. Archibald LM, Gathercole SE: Nonword repetition in specific language impairment: more than a phonological short-term memory deficit. Psychon Bull Rev 2007 14:919-924.

57. Alarcón M, Abrahams BS, Stone JL, Duvall JA, Perederiy JV, Bomar JM, Sebat J, Wigler M, Martin CL, Ledbetter DH, Nelson SF, Cantor RM, Geschwind DH: Linkage, association, and gene-expression analyses identify CNTNAP2 as an autism-susceptibility gene. Am J Hum Genet 2008, 82:150-159.

58. Verkerk AJ, Matthews CA, Joosse M, Eussen BHJ, Heutink P, Oostra BA and the Tourette Syndrome Association International Consortium for Genetics: CNTNAP2 is disrupted in a family with Gilles de la Tourette syndrome and obsessive compulsive disorder. Genomics 2003, 82:1-9.

59. Friedman J, Vrijenhoek T, Markx S, Janssen IM, van der Vliet WA, Faas BHW, Knoers NV, Cahn W, Kahn RS, Edelmann L, Davis KL, Silverman JM, Brunner HG, van Kessel AG, Wijmenga C, Ophoff RA, Veltman JA: CNTNAP2 gene dosage variation is associated with schizophrenia and epilepsy. Mol Psychiatry 2008, 13:261-266.

60. Strauss KA, Puffenberger EG, Huentelman MJ, Gottlieb S, Dobrin SE, Parod JM, Stephan DA, Morton DH: Recessive symptomatic focal epilepsy and mutant contactin-associated protein-like 2. N Engl J Med 2006, 354:1370-1377.

61. Arking DE, Cutler DJ, Brune CW, Teslovich TM, West K, Ikeda M, Rea A, Guy M, $\mathrm{Lin} S$, Cook EH, Chakravarti A: A common genetic variant in the neurexin superfamily member CNTNAP2 increases familial risk of autism. Am J Hum Genet 2008, 82:160-164

62. Bakkaloglu B, O'Roak BJ, Louvi A, Gupta AR, Abelson JF, Morgan TM Chawarska K, Klin A, Ercan-Sencicek AG, Stillman AA, Tanriover G, Abrahams BS, Duvall JA, Robbins EM, Geschwind DH, Biederer T, Gunel M, Lifton RP, State MW: Molecular cytogenetic analysis and resequencing of contactin associated protein-like 2 in autism spectrum disorders. Am J Hum Genet 2008, 82:165-173.

63. Rossi E, Verri AP, Patricelli MG, Destefani V, Ricca I, Vetro A, Ciccone R, Giorda R, Toniolo D, Maraschio P, Zuffardi O: A 12Mb deletion at 7q33-q35 associated with autism spectrum disorders and primary amenorrhea. Eur J Med Genet 2008, 51:631-638.

64. Jackman C, Horn ND, Molleston JP, Sokol DK: Gene associated with seizures, autism, and hepatomegaly in an Amish girl. Pediatr Neurol 2009, 40:310-313.

65. Poot M, Beyer V, Schwaab I, Damatova N, Van't Slot R, Prothero J, Holder SE, Haaf T: Disruption of CNTNAP2 and additional structural genome changes in a boy with speech delay and autism spectrum disorder. Neurogenetics 2009. doi: 10.1007/s10048-009-0205-1.

66. Elia J, Gai X, Xie HM, Perin JC, Geiger E, Glessner JT, D'arcy M, Deberardinis R, Frackelton E, Kim C, Lantieri F, Muganga BM, Wang L, Takeda T, Rappaport EF, Grant SF, Berrettini W, Devoto M, Shaikh TH, Hakonarson H, White PS: Rare structural variants found in attention-deficit hyperactivity disorder are preferentially associated with neurodevelopmental genes. Mol Psychiatry 2009. doi:10.1038/mp.2009.57.

67. The SLI Consortium: Highly significant linkage to the SLI1 locus in an expanded sample of individuals affected by specific language impairment. Am J Hum Genet 2004, 74:1225-1238.

68. Monaco AP, The SLI consortium (SLIC): Multivariate linkage analysis of specific language impairment (SLI). Ann Hum Genet 2007, 71:660-673.

69. Falcaro M, Pickles A, Newbury DF, Addis L, Banfield E, Fisher SE, Monaco AP, Simkin Z, Conti-Ramsden G, The SLI Consortium: Genetic and phenotypic effects of phonological short-term memory and grammatical morphology in specific language impairment. Genes Brain Behav 2008, 7:393-402.

70. Newbury DF, Winchester L, Addis L, Paracchini S, Buckingham LL, Clark A, Cohen W, Cowie H, Dworzynski K, Everitt A, Goodyer IM, Hennessy E, Kindley AD, Miller LL, Nasir J, O'Hare A, Shaw D, Simkin Z, Simonoff E, Slonims V, Watson J, Ragoussis J, Fisher SE, Seckl JR, Helms PJ, Bolton PF, Pickles A, ContiRamsden G, Baird G, Bishop DV, Monaco AP: CMIP and ATP2C2 modulate phonological short-term memory in language impairment. Am J Hum Genet 2009, 85:264-272.

71. Grimbert P, Valanciute A, Audard V, Pawlak A, Le gouvelo S, Lang P, Niaudet P, Bensman A, Guellaën G, Sahali D: Truncation of C-mip (Tc-mip), a new 
proximal signaling protein, induces c-maf Th2 transcription factor and cytoskeleton reorganization. J Exp Med 2003, 198:797-807.

72. Grimbert P, Valanciute A, Audard V, Lang P, Guellaën G, Sahali D: The Filamin$A$ is a partner of Tc-mip, a new adapter protein involved in

c-maf-dependent Th2 signaling pathway. Mol Immuno/ 2004, 40:1257-1261.

73. Kamal M: C-mip interacts physically with RelA and inhibits nuclear factor kappa B activity. Mol Immunol 2009, 46:991-998.

74. Missiaen L, Dode L, Vanoevelen J, Raeymaekers L, Wuytack F: Calcium in the Golgi apparatus. Cell Calcium 2007, 41:405-416.

75. Zheng JQ, Poo MM: Calcium signalling in neuronal motility. Annu Rev Cell Dev Biol 2007, 23:375-404.

76. Normandin L, Hazell AS: Manganese neurotoxicity: an update of pathophysiologic mechanisms. Metab Brain Dis 2002, 17:275-387.

77. Zhou K, Dempfle A, Arcos-Burgos M, Bakker SC, Banaschewski T, Biederman J, Buitelaar J, Castellanos FX, Doyle A, Ebstein RP, Ekholm J, Forabosco P, Franke B, Freitag C, Friedel S, Gill M, Hebebrand J, Hinney A, Jacob C, Lesch KP, Loo SK, Lopera F, McCracken JT, McGough JJ, Meyer J, Mick E, Miranda A, Muenke M, Mulas F, Nelson SF, et al:: Meta-analysis of genome-wide linkage scans of attention deficit hyperactivity disorder. Am J Med Genet B Neuropsychiatr Genet 2008, 147B:1392-1398.
78. Lesch KP, Timmesfeld N, Renner TJ, Halperin R, Röser C, Nguyen TT, Craig DW Romanos J, Heine M, Meyer J, Freitag C, Warnke A, Romanos M, Schäfer H, Walitza S, Reif A, Stephan DA, Jacob C: Molecular genetics of adult ADHD: Converging evidence from genome-wide association and extended pedigree studies. J Neural Transm 2008, 115:1573-1585.

79. Fisher SE, Marcus GF: The eloquent ape: genes, brains and the evolution of language. Nat Rev Genet 2006, 7:9-20.

80. Terracciano A, Sanna S, Uda M, Deiana B, Usala G, Busonero F, Maschio A Scally M, Patriciu N, Chen WM, Distel MA, Slagboom EP, Boomsma DI, Villafuerte S, Sliwerska E, Burmeister M, Amin N, Janssens AC, van Duijn CM, Schlessinger D, Abecasis GR, Costa PT Jr: Genome-wide association scan for five major dimensions of personality. Mol Psychiatry 2008. doi: 10.1038/mp.2008.113.

doi:10.1186/gm127

Cite this article as: Newbury DF, et al.: Recent advances in the genetics of language impairment. Genome Medicine 2010, 2:6. 